\title{
A Case Study of Racial Exclusion and Incarceration in the Midwest: Illinois before the Carceral State
}

\author{
Robert Scott
}

\section{Introduction}

Outrage over the 2014 police killings of Michael Brown near St. Louis and Laquan McDonald in Chicago triggered waves of protest against police mistreatment of African Americans. Demonstrations under the banner of "Black Lives Matter" have been fueled by video footage of police killings and the exoneration of police in the rare instances in which such killings have been brought to trial. These two flashpoints of the current movement-Ferguson, Missouri, and a peripheral neighborhood of Chicago near Cicero, Illinois - are not arbitrary. They are part of a struggle over the station of black citizens in the Midwest that goes back to the colonial settlement of the region and the struggle over slavery. Tracing the predecessor species of the carceral state in the Midwest may help us understand the present dilemma in the United States.

Critical prison studies have shown how today's racialized mass incarceration of black people grew out of the 1960s and 1970s, a sort of political revanchism that developed in response to the Civil Rights Era. ${ }^{1}$ Others have written about how crime provided cover for racial discrimination and the denial of rights much earlier, extending the timeline back to slavery. ${ }^{2}$ In the pages that follow, I investigate how nineteenth- and early-twentieth-century prisons were germane to the evolving racial order and social control in the Midwest. Past scholarship has illuminated the racist roots of prisons that were formerly slave 
plantations in the South (e.g., Angola and Parchman) that still operate in today's vast penal archipelago. ${ }^{3}$ But what about nonslave states and the carceral systems they developed during the same period? How was racial control formative of the early landscape of an ostensibly antislavery state such as Illinois? How do the original penitentiaries located near St. Louis and Chicago fit into the history of race and policing in America's breadbasket?

In tracing the origins of the Illinois penitentiary system, this paper contributes to the genealogy of American prisons. ${ }^{4}$ The relevance of this study derives from the fact that the United States incarcerates a greater proportion of its citizens than any other nation, and the majority of prisoners are African American. ${ }^{5}$ Most U.S. prisoners are incarcerated in state prisons and local jails. ${ }^{6}$ This raises a historical question: How did states that fundamentally disagreed on slavery in the nineteenth century converge upon the mass incarceration of African Americans in the twentieth century? This essay looks for clues in the proto-carceral state. Illinois developed its first prisons during the nineteenth century; the young state sided with the Union in the Civil War (the "Land of Lincoln") but simultaneously set about establishing a racially segregated pattern of settlement throughout the state. This apparent contradiction would parallel subsequent contradictory developments such as the rise of "color-blind racism" and the legal discrimination against felons. ${ }^{7}$ This paper looks at the ways in which earlier paradigms of racial segregation interacted with the developing carceral system before the emergence of racial mass incarceration in the late twentieth century. My hope is that an understanding of the currents of history that are traced in this study of Illinois may inform the struggles for justice that continue to this day.

\section{Before the Civil War: The Bracketing of Black Life and of Punitive State Violence}

Native Americans were forcibly removed and slavery was banned from Illinois before it was admitted as a state in $1818 .{ }^{8}$ Although it was admitted as a nonslave state, much of its population lived in the southern part of the state, which was culturally connected to the South, particularly the southern tip of Illinois, which was sandwiched between the slave states of Missouri and Kentucky. Though slavery was outlawed, it persisted in this far southern end of the state, nicknamed "Little Egypt." Cotton and tobacco were raised by slaves in the southernmost counties during the first decades after the state was established. Free African descendants in Illinois lived in the limbo status of noncitizenship while white Illinois residents generally did all they could to minimize their presence. ${ }^{9}$ The U.S. Fugitive Slave Act (1850) and Illinois's subsequent "negro exclusion bill" (1853) codified the legality of excluding black people from living in the state. ${ }^{10}$ The laws were ultimately ineffectual in that several thousand black people lived in Illinois in the decades leading up to the Civil War.

Illinois was a state of contradiction - opposed to slavery on the one hand, but opposed to the free black bodies produced by emancipation on the other. 
Attempts to resolve the contradiction by legalizing slavery failed in 1825 , and attempts to remove the remaining black population failed when white citizens refused to do the dirty work of expulsion after the 1853 bill. The free black population grew by 50 percent between 1810 and 1850, though the corresponding proportion of the Illinois population fell from 5 percent to less than 1 percent during the same period. ${ }^{11}$ The low proportion of African descendants in the state contributed to a sense of denial and nonconsideration of black people amongst the white residents of Illinois.

Was there a racial dynamic to the matrix of policing and prisons during this early period of Illinois history? Initially, serious crimes were punished with lashes in the public square, and possibly a short sentence in a regional jail. ${ }^{12}$ Corporal punishment was unpopular, and the Illinois State Penitentiary opened in 1833 at Alton, Illinois, accompanied by a concurrent act that outlawed flogging as criminal punishment for Illinois citizens (while transferring the power of flogging to the prison warden). ${ }^{13}$ The rough conditions of life at Alton inspired Illinois's first prison reformer, Dorothea Dix, who left behind some of the most complete and critical descriptions of conditions at the (short-lived) Alton Penitentiary. ${ }^{14}$ The prison was described as crowded, underresourced, and noisy-Dix's central complaint was that it had failed to emulate the enforced silence called for by the Pennsylvania model.

Although slavery and corporal punishment were both formally outlawed, in practice the violent coercion of black labor and punitive violence against convicts were simply bracketed and removed from the public gaze. ${ }^{15}$ Note that because of the denial of the rights of citizenship, freedmen were not covered by the ban on corporal punishment during this period. While the Illinois legislature debated how to block noncriminal black people from entering the state, it also began to seriously consider passing reforms for its predominantly white prisoners. ${ }^{16}$ To improve prison conditions, Illinois built a new penitentiary in Joliet and closed the Alton prison after briefly using it to hold Confederate soldiers during the Civil War.

Illinois embodied the tension between Northern and Southern racial attitudes during and after the Civil War. Abraham Lincoln's political career had begun in Illinois, and the young state had fought with the Union army during the Civil War, but African Americans were treated with contempt long after the war was won. ${ }^{17}$ When Lincoln lived in Illinois, racial coexistence consisted in a segregated two-tiered society in regard to geography, economic opportunity, and legal rights. After the war, the state's white population was politically divided on the question of black rights. The geography of the state reinforced the division: although Chicago was closely connected to New England via Great Lakes shipping routes, Illinois's 20 million acres of farmland were culturally closer to adjacent agricultural states. The postbellum racial project chiefly focused on protecting white access to this land. 


\section{After the Civil War: Racial Division and Prison Reform}

As settlers converted Illinois' prairies into arable farmland, they also cultivated a racially segregated social space. African Americans who migrated northward into Illinois found a white population that had barely been exposed to black people, and the resulting dynamic between the two groups was one of suspicion, exploitation, and exclusion. During the late nineteenth and early twentieth centuries, riots and expulsions resulted in large areas becoming designated as hostile to the presence of black people, such that there were fewer counties with black residents in 1930 than there were in $1890 .{ }^{18}$ Meanwhile, Chicago had become a destination city of immigrants and migrating freedmen.

Illinois' new prisons reflected its divided geography. The Illinois State Penitentiary opened in Joliet (near Chicago) in 1858, and the Southern Illinois Penitentiary was opened in the town of Chester (near St. Louis) in $1878 .{ }^{19}$ When calls for change helped launch the reformatory movement, Illinois responded by creating the Pontiac Reform School for boys in $1871 .{ }^{20}$ In 1896, a women's annex at Joliet became the final addition to Illinois' three neoclassical prisons of the nineteenth century: a northern penitentiary near Chicago (Joliet), a midstate institution for delinquent juveniles (Pontiac), and a southern penitentiary near St. Louis (Chester). At the turn of the century, 2,086 people were housed in Illinois prisons, there was no centralized authority, and the facilities operated independently of one another. ${ }^{21}$

During the same period, many "sundown towns" developed in Illinois. Sundown towns were municipalities that prevented African Americans from living in them, oftentimes by enforcing a rule that nonwhites had to leave town at sundown (i.e., could not reside there). ${ }^{22}$ During the early twentieth century, many Illinois towns with black residents were converted into sundown towns as the result of pivotal events (e.g., race riots) that would purge (or kill) the black residents present and establish an all-white city. Sundown towns existed throughout Illinois, and southern Illinois is known to have had many [Figure 1]. Sundown towns are important for two reasons: first, they contradict the narrative that black people "self-segregated" as they moved northward after the Civil War, and, second, they represent a distinct form of racial exclusion that left virtually no written record in terms of policies on the books, although they are studied today through oral history. ${ }^{23}$ The latter should be instructive to those who critique present-day "color-blind" racism; in a sundown town one did not need to attribute crime to a black person to exclude them, and this absence of documentation belied a project of racial segregation that both stretched across the state and lacked central authority.

One might ask then, reasonably, whether and how Illinois prisons and jails served the racial status quo. Unlike the prisons of the deep South, the Illinois penal system that developed after the Civil War did not reproduce conditions of slavery. ${ }^{24}$ First, most Illinois prisoners in the early twentieth century were white. ${ }^{25}$ Convict leasing was limited to light industrial rather than agricultural 


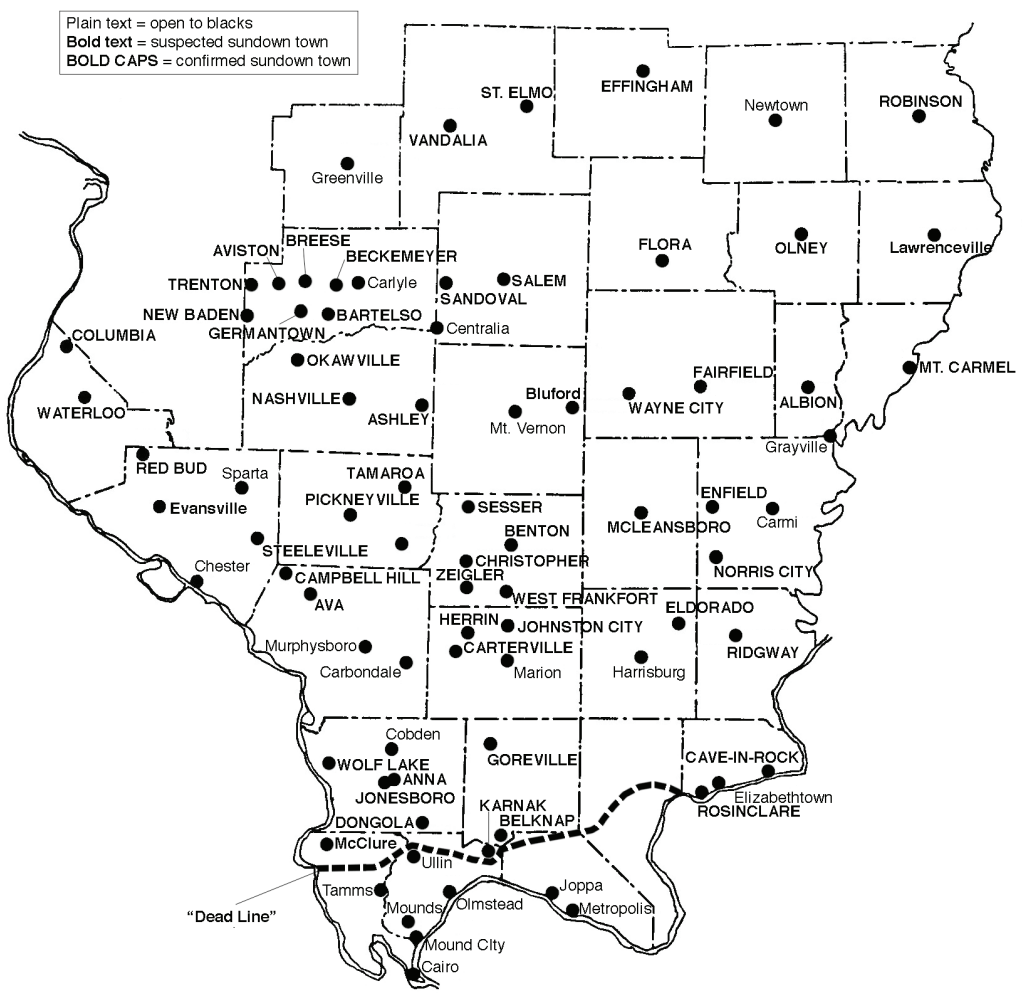

Figure 1: Map of sundown towns in Southern Illinois, circa 1952. Reproduced with permission from James Loewen, who writes "the dotted line at the bottom is the 'dead line,' north of which African Americans were not allowed to live (except in unbolded towns). South of this line, cotton was the major crop; white landowners employed black labor, following the southern tradition of hierarchical race relations rather than northern sundown policies. All 8 towns below this line allowed African Americans to live in them. Among the 72 towns above the line, only 18 - a quarter - did so to my knowledge." ${ }^{26}$

work, and it was restricted to workshops inside prison walls after the war. ${ }^{27}$ Illinois prisoners were forced to quarry and crush rock for roadways, and the biggest benefactor of the free prison labor was the state. ${ }^{28}$ The carceral logics of Illinois were not articulated in racial terms at this time, save for the call to keep the children of European immigrants out of the penitentiary.

The movement to separate adult and juvenile justice systems led to the establishment of the nation's first juvenile court in Chicago in 1899. ${ }^{29}$ By 1907, the court and detention center had a building of their own that coordinated with Jane Addams' Hull House to help educate the children in their custody. ${ }^{30}$ The juvenile court was designed to divert youth from the adult prison system, and it 
was specifically oriented to the needs of the children of immigrants; as Addams herself remarked, "four-fifths of the children brought into the Juvenile Court in Chicago are the children of foreigners." ${ }^{31}$ Hull House hosted a weekly meeting of the Juvenile Protective Association, which sought "to treat the youth of the city with consideration and understanding" in accord with the House's mission of providing services and programs to immigrant communities. ${ }^{32}$

Contrast the sympathy afforded to European immigrants with the fact that black children were simultaneously facing Jim Crow laws. ${ }^{33}$ Racial discrimination in America had endured the provision of citizenship and voting rights to African Americans, and the racial segregation of public schools was upheld by the Supreme Court in $1896 .{ }^{34}$ But prison did not play a leading role in creating a racially segregated society in nineteenth-century Illinois; only a few hundred black people ended up in prison. ${ }^{35}$ At the turn of the century, the Illinois prison system was focused on implementation of proto-rehabilitative ideas: providing discretionary parole release, meritorious good time, and indeterminate sentencing. ${ }^{36}$ The station of white criminals improved while noncriminal black citizens faced exclusion and discrimination. ${ }^{37}$

\section{Twentieth-Century Illinois: Rehabilitation and Segregation}

The concept of rehabilitation or "corrections" in prison truly blossomed in the twentieth century at a time when about 80 percent of Illinois prisoners were white. ${ }^{38}$ Two new rehabilitation-oriented prisons, the Illinois State Farm for Misdemeanants (opened in 1921) and the Illinois State Reformatory for Women (opened in 1930), were located in sundown towns..$^{39}$ These were prisons designed to rehabilitate the predominantly white prisoners - a farm and a reformatory —in towns that had removed all free black citizens. ${ }^{40}$ These towns received their only black residents in chains.

The enforcement of Prohibition provoked a racial reconsideration of what is a crime and who is considered a criminal. If we compare the Prohibition Era to the War on Drugs today, several striking parallels and discrepancies emerge. As Khalil Muhammad has pointed out, both led to a growth of the prison population and new prison construction; the rise of "four strikes" laws in the 1920s parallel the "three strikes" laws of the 1990s; both ultimately led to outcries over excessive punishment. ${ }^{41}$ Some have argued that the comparatively speedy repeal of Prohibition resulted from the brutalization and incarceration of European-descended Americans, whereas the more recent war on drugs has taken advantage of latent racism against African Americans. ${ }^{42}$ The former is evidenced in a Chicago Tribune editorial of October 1923:

Mayor Dever's seven thousand policemen face a city which rejects the law they try to enforce. The city still eludes the enforcement. Half a million people in Chicago whose mother tongue was German nearly all have a profound convic- 
tion against the prohibition of beer. Not one per cent of the 166,500 whose mother tongue was Italian or Greek can believe that wine is morally bad or can be made bad by law. ${ }^{43}$

The public was outraged when a life sentence was given to a white man who possessed a pint of gin; similar fury erupted when innocent white fatalities resulted from high-profile liquor raids in Chicago. ${ }^{44}$

The enforcement of Prohibition (1920-1933) enlarged the prison system; Illinois's largest prison population (Joliet) in 1920 was 1,474, but a decade later it had almost tripled to $4,167 .{ }^{45}$ Strikingly, the rise in incarceration was not accompanied by theories about alcohol being a gateway drug. There was no mention of alcohol addiction or abuse as a cause of other index crimes in the state criminologists' reports (compare this to Illinois Department of Corrections reports in the 1990s arguing for a link between illegal drugs and violent crime) ${ }^{46}$ Rather, criminological diagnoses, with their emphasis on psychometrics, embodied a "subtle shift in the conception of the criminal as sinner to the criminal as sick, needing specialized diagnosis and treatment." ${ }^{\text {"47 }}$ This paradigm of rehabilitation emerged triumphant from America's first war on drugs (against alcohol) fueled by white anxiety over the policing of European immigrants. After Prohibition was repealed, Illinois did not build another prison until the 1960s [Table 1].

Illinois' prison population was cut in half between 1940 and $1973 .{ }^{48}$ Meanwhile, unprecedented access to communication and education was made available to prisoners. Prison newspapers were launched that allowed men in prison to communicate inside and outside prison walls. ${ }^{49} \mathrm{After}$ a 1952 prison riot at the Southern Illinois Penitentiary, the warden invited Southern Illinois University of Carbondale (SIU-C) faculty to teach a course on journalism at the prison, which was the first college course ever offered inside a prison. ${ }^{50}$ In subsequent years SIU-C hired forty staff to run their college-in-prison programs, which offered four-year degrees inside the walls of the prisons at Menard, Centralia, Vienna, and Shawnee. ${ }^{51} \mathrm{~A}$ new prison opened in the sundown town of Vienna on November 23, 1965.52 SIU-C began offering its college program there in October 1966, and it was estimated in July 1967 that 75 percent of the population was "involved in the GED or college courses." ${ }^{53}$ Although the approbation of prison newspapers and college programs signaled a relatively high level of respect for the prisoner, the late 1960s marked a turning point in race relations and criminal justice.

The Illinois prison system was not a race-neutral institution at the end of the 1960s. It had evolved as a reformed institution predominantly in the interest of white citizens since the end of Prohibition. The state's three newest prison towns (Vandalia, Dwight, and Vienna) were sundown towns. The growth of prison education programs during the 1950s and 1960s was contemporaneous with the rise of the Civil Rights movement. But the era drew to a close as the latter gave way to more militant forms of struggle in the political movements of the late 1960s and early 1970s, and Illinois was a key theater in the conflict. ${ }^{54}$ 


\section{Robert Scott}

Table 1: Illinois state prisons, organized chronologically by the year in which the prisons opened, and the administration operating at the time the prisons were opened. This table does not include juvenile prisons, federal prisons, county jails, "community correctional centers," or prison-administrated "adult transition centers" or halfway houses. They are beyond the scope of this study.

Prison City (Alternative Name, if Applicable)

\begin{tabular}{|c|c|c|}
\hline Alton & $1833-1860$ & (Independently run) \\
\hline Joliet & $1858-2002$ & \\
\hline Chester (Menard) & 1878 & \\
\hline Joliet (Women's Annex) & $1896-1932$ & \\
\hline Vandalia (Illinois State Farm) & 1921 & Dept. of Public Welfare \\
\hline Joliet (Stateville) & 1925 & \\
\hline Dwight (Women's Reformatory) & $1930-2013$ & \\
\hline Pontiac* & 1933 & \\
\hline Vienna & 1965 & Dept. of Public Safety \\
\hline Sheridan* & 1973 & Dept. of Corrections \\
\hline Lincoln (Logan Correctional Center) & 1978 & \\
\hline Centralia & 1980 & \\
\hline East Moline & 1980 & \\
\hline Hillsboro (Graham Correctional Center) & 1980 & \\
\hline Dixon & 1983 & \\
\hline Jacksonville & 1984 & \\
\hline Lincoln (separate from Logan Correctional Center) & 1984 & \\
\hline Vienna (Shawnee Correctional Center) & 1984 & \\
\hline Danville & 1985 & \\
\hline Galesburg (Hill Correctional Center) & 1986 & \\
\hline Canton (Illinois River Correctional Center) & 1989 & \\
\hline Mt. Sterling (Western Illinois Correctional Center) & 1989 & \\
\hline Taylorville & 1990 & \\
\hline Robinson & 1991 & \\
\hline Ina (Big Muddy River Correctional Center) & 1993 & \\
\hline East St. Louis (Southwestern Correctional Center) & 1995 & \\
\hline Pinckneyville & 1998 & \\
\hline Tamms & $1998-2012$ & \\
\hline Decatur & 2000 & \\
\hline Sumner (Lawrence Correctional Center) & 2001 & \\
\hline Savanna (Thomson Correctional Center) $\dagger$ & $2001-2010$ & \\
\hline
\end{tabular}

$1833-1860$

$1896-1932$

$1930-2013$

Dept. of Public Safety

Dept. of Corrections

Years
Open-Closed Administration

*Pontiac and Sheridan were previously run as juvenile facilities before being converted to adult prisons.

†Thomson was intended as a maximum-security prison but was opened with a small minimumsecurity population; it was permanently closed in 2010 and sold to the Federal Bureau of Prisons in 2012 . 
The Illinois prison population became more than 50 percent black for the first time in $1969 .{ }^{55}$ Prison politics came to the political foreground across the nation with the rise of George Jackson in the struggle for black freedom, whose death in a California jail was soon followed by the Attica prison riot of 1971. Since that time, the prison population in Illinois has grown dramatically, and the proportion of Illinois prisoners that are nonwhite has grown as well [Figure 2]. Similar to sundown towns, prison towns were not launched with formal racial policies but rather were organized via carefully coded sociocultural messaging that linked (nonwhite) race with crime ${ }^{56}$ The Illinois prison system grew larger and increasingly incarcerated black bodies within its walls after 1969, while the color-blind referent "criminal" was mobilized in a civic discourse that would justify the decline of rehabilitation programs inside prison, and the denial of right and services without. ${ }^{57}$

David Garland used the phrase "the punitive turn" to describe the societywide turn toward increased use of imprisonment, longer sentences, and harsher prison conditions.$^{58}$ Illinois took the turn along with much of the country, pledging to fight the "war on drugs" and expanding incarceration through specific actions such as the mandatory sentencing bill of $1976 .{ }^{59}$ Through this paper I have suggested that the desire of the white community to exclude the participation of nonwhite people from society would seem a logical historical assumption. By

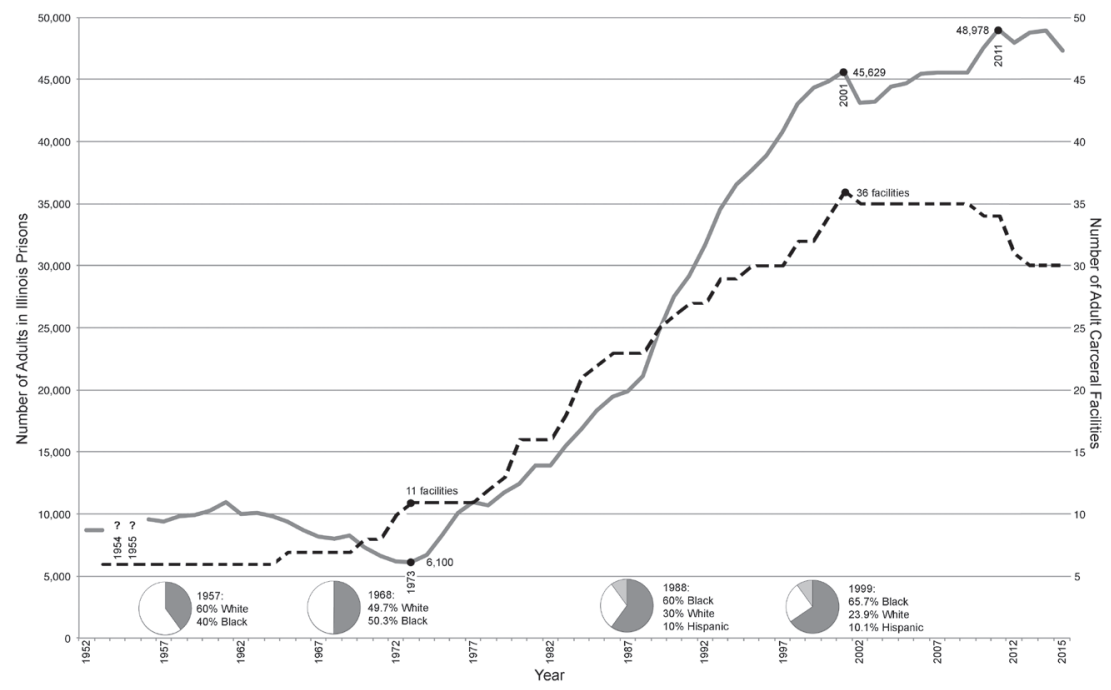

Figure 2: Number of adults in Illinois prisons (gray line) and number of carceral facilities (dashed line) and proportion of prison population from different racial groups (pie charts) from 1952 to 2013. Note that "carceral facilities" includes 7 adult transition centers administered by the Illinois Department of Corrections. Data compiled from the Annual Reports of the Illinois Department of Public Safety, and the Illinois Department of Corrections. 
the 1980s, Illinois towns were actually lobbying to become prison towns, sometimes in the very municipalities that had formerly been sundown towns. One absurd example comes from Flora, Illinois, where the city's all-white leadership came together to compose a rap song and video asking then-governor James Thompson to build a prison in their town. The police chief, local newspaper publisher, and mayor of Flora all rapped about their desire for Illinois to build a prison in Flora ${ }^{60}$ The song never mentions race explicitly, but it was carrying forward a pattern of race relations that leads up to the present crisis around (black) community-police relations today.

\section{Conclusion}

This brief genealogy of early Illinois racial and carceral logics reveals that geographic and municipal exclusion was a key instrument of racial control before incarceration superseded it. Illinois penitentiaries chiefly contained white prisoners during the period covered in this essay, but the institutionalization of incarceration represented a new form of segregation that would rapidly expand with the hyperpolicing of the 1970s and 1980s. It stands to reason that in a state where racial discrimination was contentious, the structure of institutional racism would become a moving target, both spatially and temporally. There was not a direct one-to-one transference of sundown towns to prison towns, though a region that was known to have 52 sundown towns now operates 46 jails and prisons [Figures 1 and 3]. County legislatures did not mandate minimum sentences or police profiling in the name of Jim Crow. The transference of racial exclusion to the carceral state was in many regards indirect. This nonlinear path from earlier forms of institutional racism contributes to the tendency of critical prison studies to linger in the theoretical.

In a sense, the project of segregation underwent reconstruction as earlier structures of institutional racism were outlawed; thus today rights are not denied to people constructed as "black" but rather people constructed as "criminal." On the eve of mass incarceration, sociologists were arguing that prisons never succeeded in establishing programs that successfully rehabilitated prisoners. ${ }^{61}$ One may derive that a well-functioning prison serves to segregate that class of individuals deemed to be "criminal" in such a manner that the public accepts the implicit violence of segregation. Perhaps the televised actions of the Civil Rights Era showed white America that there was no "elsewhere" left to segregate people; the only way to send people "away" was to send them to jail: "The mission of the [Illinois] Department of Corrections is to protect the public from criminal offenders through a system of incarceration and supervision which securely segregates offenders from society." 62

Language can function like a smoke screen, obfuscating the underlying historical forces and interests that run the system. I would not be alone in arguing that words like "security," "criminal," and "custody" have contributed to 


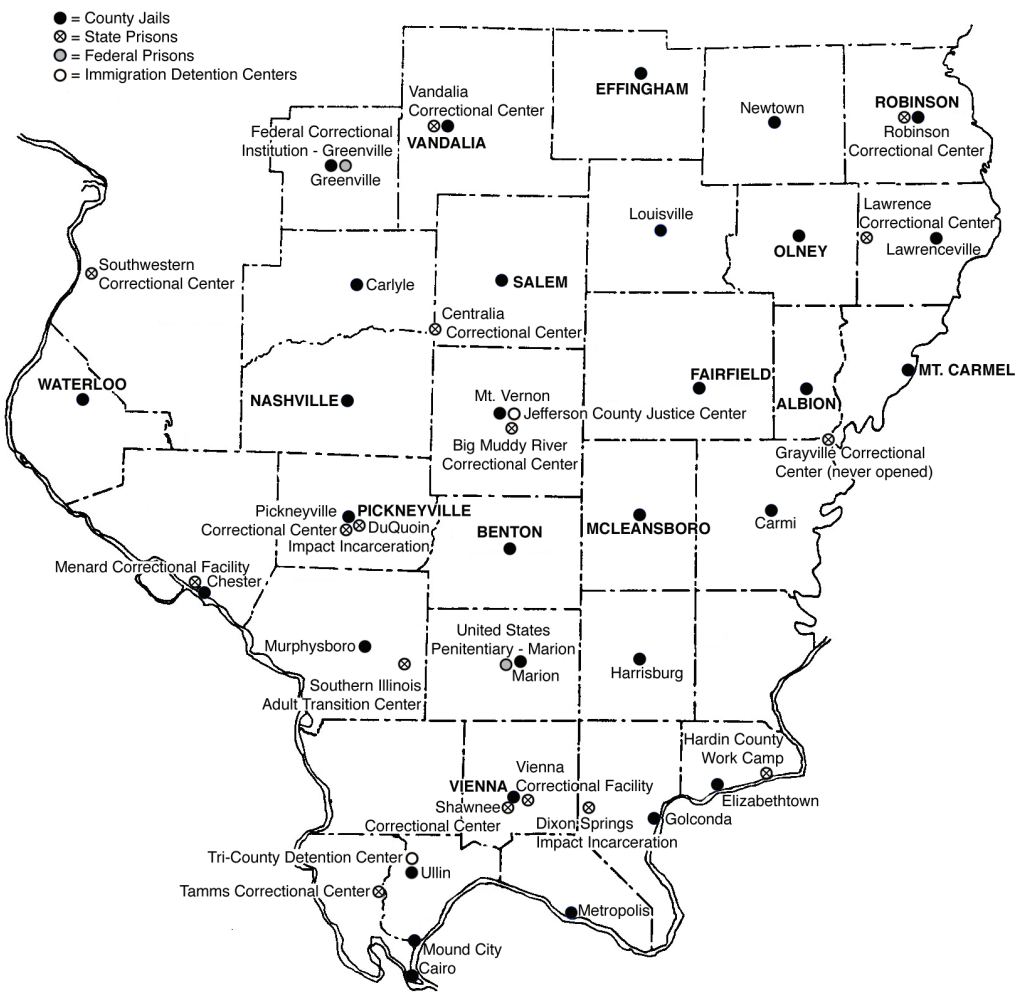

Figure 3: Locations of county jails, state prisons, federal prisons, and immigrant detention centers in Southern Illinois, circa 2015. Cities whose names appear in BOLD CAPS are confirmed former sundown towns referenced in Figure 1.

a new chapter of the institutional cultivation of a racial underclass, a veritable "new Jim Crow." ${ }^{63}$ The chief contribution of this paper has been to show that during the old Jim Crow, earlier forms of prison evolved in symbiosis with concepts of racial discrimination and geographic segregation that were part of the original blueprint for social order in Illinois. "Rehabilitation" became the watchword in prisons when the average prisoner was white, and thus "correctional" institutions bound their predominantly white prisoners to aspects of racial and economic apartheid that would reemerge when the torch of institutional racism was handed to America's prisons amid the waning of the Civil Rights era.$^{64}$ While policing and prisons are currently a flashpoint for race relations in the United States, the roots of the problem run far deeper than what is observed on the surface. 


\section{Notes}

1. Loïc Wacquant, "Class, Race \& Hyperincarceration in Revanchist America," Doedalus 139 (2010): 74-90. Heather Ann Thompson, "Why Mass Incarceration Matters: Rethinking Crisis, Decline, and Transformation in Postwar American History," Journal of American History 97 (2010): 703-734. Of specific relevance to the geo-spatial look at the prison boom presented in this paper is Ruth Wilson Gilmore, Golden Gulag: Prisons, Surplus, Crisis, and Opposition in Globalizing California (Berkeley: University of California Press).

2. Michelle Alexander, The New Jim Crow: Mass Incarceration in the Age of Colorblindness (New York: New Press, 2010). Khalil Gibran Muhammad, The Condemnation of Blackness: Race, Crime, and the Making of Modern Urban America (Cambridge, MA: Harvard University Press, 2011). Jordan T. Camp, Incarcerating the Crisis: Freedom Struggles and the Rise of the Neoliberal State (Oakland: University of California Press, 2016). Ava DuVernay, 13th (Netflix documentary, 2016).

3. David M. Oshinsky, Worse than Slavery: Parchman Farm and the Ordeal of Jim Crow Justice (New York: Simon and Schuster, 1996). Douglas A. Blackmon, Slavery by Another Name: The Re-enslavement of Black People in America from the Civil War to World War II (New York: Doubleday, 2008).

4. The growth of the American prison system has ample literature that touches upon, but does not fully develop, the story of Illinois' prison system. See Norval Morris and David J. Rothman (eds.), The Oxford History of the Prison (New York: Oxford University Press, 1995), for an introductory history and a look at prison influences on either side of the Atlantic. Michel Foucault endeavored to lay out the birth of the prison as a paradigm of social control; see Michel Foucault, Discipline and Punish: The Birth of the Prison (New York: Random House, 1977). Others have looked at the sociology of incarceration in the more recent era, which I describe as the "decline of corrections"; see Bruce Western, Punishment and Inequality in America (New York: Russell Sage Foundation, 2006). The American Correctional Association published a look at the origins of the system that casts the system in a light of continuous quality improvement. More recent studies have focused on the current prison system, using the earlier history chiefly as a backdrop against which to juxtapose the explosion of the prison population after the 1960s; see American Correctional Association, The American Prison: From the Beginning (USA: American Correctional Association, 1983).

I am indebted to several scholars who have tackled prison and race relations in Illinois. See Paul Street, The Vicious Cycle: Race, Prison, Jobs, and Community in Chicago, Illinois, and the Nation (Chicago: Chicago Urban League, Department of Research and Planning, 2002); see also Erica Meiners, "Resisting Civil Death: Organizing for Access to Education in Our Prison Nation," Depaul Law School Justice Journal 3 (2009): 79-95. I have also taken inspiration from the work of Miriame Kaba and Project NIA as well as various nonprofits and think tanks from around the country that have tracked Illinois, or Chicago in particular, in relation to nationwide trends in policing and incarceration of communities of color.

5. Roy Walmsley, "World Prison Population List," 8th ed., International Centre for Prison Studies, accessed March 12, 2013, http://www.prisonstudies.org/info/downloads/wppl-8th 41.pdf. For a racial breakdown of U.S. prison populations by state, see Prison Policy Initiative, " $\overline{5} 0$ State Incarceration Profiles" accessed September 14, 2014, http://www.prisonpolicy.org/profiles/. The percentage of Illinois prisoners who were African American in 2010 was 56 percent.

6. Peter Wagner and Leah Sakala. "Mass Incarceration: The Whole Pie," accessed September 14, 2014, http://www.prisonpolicy.org/reports/pie.html.

7. See Alexander, The New Jim Crow, 2.

8. Slavery had been banned by the Northwest Territory Ordinance of 1787 , and Native Americans with territorial claims were largely removed before statehood (although some would attempt to return). Additionally, the Illinois Territory passed a law in 1813 prohibiting free black people from entering Illinois.

9. Steven J. Savery, "The Free Negro in Illinois prior to the Civil War" (master's thesis, Eastern Illinois University, Charleston, 1986).

10. Illinois African slaves were brought in periodically to do seasonal work, and freedmen were barred from citizenship; see James Pickett Jones, Black Jack: John A. Logan and Southern Illinois in the Civil War Era (Carbondale: Southern Illinois University Press, 1967), 17-20. For more on Little Egypt see Sarah Lewison, "Little Egypt," in Deep Routes: The Midwest in All Directions (Chelsea, MI: White Wire, 2012), 93-103.

11. United States Census Bureau. Statistical View of the United States. Compendium of the Seventh Census (Washington, DC: Beverly Tucker, Senate Printer, 1854).

12. For a more fulsome discussion of the transition from corporal punishment to prison, see "Chapter 4: The Policy of Punishment in Early Illinois" in The Workings of the Indeterminate-Sentence Law and the Parole System in Illinois, ed. Andrew A. Bruce, Ernest W. Burgess, and Albert J. Harno (Chicago: Committee on the Study of the Indeterminate-Sentence Law and the Parole System in Illinois, 1928). 
13. Lightner, Asylum, Prison, and Poorhouse; Bruce, Burgess, and Harno, Workings of the Indeterminate-Sentence Law, 25.

14. See the second chapter of Lightner, Asylum, Prison, and Poorhouse, which includes a few of Dix's letters to the Illinois legislature from the 1840s. Dix called for the building of a new prison and the demolition of the prison at Alton; ultimately, she was advocating the Pennsylvania model over the Auburn system.

15. Slavery existed in Illinois territory and persisted after Illinois became a state in 1818 . Concurrent antislavery sentiments (such as that of Elijah Lovejoy) existed in the state, and forms of indentured servitude existed during the first decades after statehood. See Norman Dwight Harris, The History of Negro Servitude in Illinois, and of the Slavery Agitation (Chicago: R. R. Donnelley \& Sons, 1904).

16. Mark Hubbard, Illinois 's War: The Civil War in Documents (Athens: Ohio University Press, 2013), 16-20.

17. John J. Dunphy, Abolitionism and the Civil War in Southwestern Illinois (Charleston, IL: History Press, 2011), 107-147.

18. James W. Loewen, Sundown Towns: A Hidden Dimension of American Racism (New York: Simon \& Schuster, 2005), 56.

19. The prison at Alton, Illinois opened in 1833 and closed after ISP-Joliet opened in 1858, although it was converted into a federal military prison during the Civil War. Between 1862 and 1865 the prison at Alton held more than 10,000 Confederate soldiers as prisoners. Also note that the Southern Illinois Penitentiary near Chester is now part of a small town called Menard (Menard Correctional Center), although for several decades it was associated only with the nearby town of Chester.

20. Edgardo Rotman, "The Failure of Reform: United States, 1865-1965," in The Oxford History of the Prison: The Practice of Punishment in Western Society ed. Norval Morris and David J. Rothman (New York: Oxford University Press, 1995), 171-176.

21. To determine the 1900 Illinois adult prison population I combined head counts for October 1, 1900, from the following two sources: Report of the Southern Illinois Penitentiary at Chester (Springfield, IL: Phillips Bros. State Printers, 1902) and Report of the Commissioners of the Illinois State Penitentiary at Joliet (Springfield: Phillips Bros. State Printers, 1903).

22. Loewen, Sundown Towns, 3-4.

23. Loewen, Sundown Towns, 99-100.

24. Oshinsky, Worse than Slavery: Parchman Farm and the Ordeal of Jim Crow Justice (New York: Simon and Schuster, 1996).

25. See note 33. Also, as late as the 1950s reports were that the majority of Illinois state prison population was white. A 1959 report on 1957 and 1958 visits to various Illinois prisons quantifies the nonwhite population as follows: Illinois State Penitentiary, Menard Branch = 38\% "colored"; Illinois State Penitentiary, Pontiac $=40 \%$ "colored." Dwight P. Friedrich, Otis L. Miller, Morris E Muhleman, Albert Scott, J. Lisle Laufer, and George L. Saal, Report of the Penal Division of the Commission to Visit and Examine State Institutions (1959 Reports).

26. Loewen, Sundown Towns, 62.

27. On source describes the prison at Alton leasing out one-quarter of its men in 1845 for "the manufacturing of hempen articles" provided that the lessee was to provide guards, food, clothes, and bedding for the prisoners working on his land. See Bruce, Burgess, and Harno, Workings of the Indeterminate-Sentence Law, 26. At Menard, "prisoner labor was used by the Pettengill Boot and Shoe Company ... another workshop was requested by the commissioners to put more inmates to work"; see Jeffrey Koerber and Walter L. Brieschke, "Menard: Development of a Nineteenth-Century Prison," Journal of the Illinois State Historical Society 96 (2003): 233.

28. Koerber and Brieschke, "Menard," 239. Prisoners at Joliet Penitentiary quarried 87,500 cubic yards of rock annually, which were given away free for road improvements in the counties of Illinois. See The Joliet Prison Post 1 (January 1, 1914): 29. This prison newspaper also called the use of prisoners for highway construction a humiliation on the preceding page.

29. Illinois Juvenile Court Act. 1899. Ill. Laws 132 et seq. The Chicago Visitation and Aid Society claimed credit for having created the juvenile court, although others point instead to earlier involvement of courts and surrounding agencies, noting, for instance, that in 1888 the Illinois Supreme Court barred county courts from turning children over to organizations such as the Visitation and Aid Society. See Sanford J. Fox, "The Early History of the Court," in The Future of Children 6 (1996): 33. In any case there appears to have been debate among politicians and humanitarian societies in Chicago over the fate of juveniles accused of serious crimes. and 325 .

30. Jane Addams, Twenty Years at Hull-House (Norwood, MA: Norwood Press, 1910), 232-234

31. Addams, Twenty Years at Hull-House, 252.

32. Addams, Twenty Years at Hull-House, 235-236.

33. An account of the Jim Crow policies effecting Chicago can be found in Ta-Nehisi Coates, "The Case for Reparations: A Narrative Bibliography," The Atlantic (June 2014). 
34. See Supreme Court decision favoring racial segregation in public institutions such as schools: Plessy v. Ferguson, 1896, 163 U.S. 537, 16 S. Ct. 1138; 41 L. Ed. 25.

35. The Illinois prison population was 12.4 percent "colored" in 1884 ; see "Section G. Report Commissioners Penitentiary at Joliet," in Reports to the General Assembly of Illinois, vol. 2 (Springfield, IL: H. W. Rokker, State Printer and Binder, 1885) 68, and "Section H. Report Commissioners Penitentiary at Chester," in Reports to the General Assembly of Illinois, vol. 2 (Springfield, IL: H. W. Rokker, State Printer and Binder, 1885) 64. In 1901, the Illinois penitentiaries admitted 613 (78.4 percent) new white convicts and 169 (21.6 percent) new "negro" convicts. See Report of the Commissioners of the Illinois State Penitentiary at Joliet for the Two Years Ending September 30, 1902 (Springfield, IL: Phillips Bros., State Printers, 1903), 68, and Report of the Southern Illinois Penitentiary at Chester for the Two Years Ending September 30, 1902 (Springfield, IL: Philips Bros., State Printers, 1902), 42.

36. Parole was first created in the General Parole Act of 1895. It was amended in 1897 to provide for indeterminate sentences for those eligible for parole. In the Illinois Criminal Code of 1897, see Chapter 38, $\$ 498$, Part 1, on indeterminate sentencing and $\$ 502$, Part 2, on parole independent of pardon. Finally, the final revision termed the Indeterminate Sentencing and Parole Law of Illinois came into force July 1, 1899. Basically, with the exception of the crimes of murder, treason, manslaughter, and rape, those convicted in Illinois courts were to receive an indeterminate sentence between the minimum and maximum provided for by law, and respecting the awards of good time already in effect within the state. See chapter 10 in Bruce, Burgess, and Harno, Workings of the Indeterminate-Sentence Law.

37. Youthful European immigrants in Chicago would assimilate and acquire white privilege in subsequent years; see James R. Barrett and David Roediger, "How White People Became White" in White Privilege: Essential Readings on the Other Side of Racism, ed. Paula S. Rothenberg (New York: Worth Publishers, 2001), 29-34. A 1904 book that promoted the new juvenile court included twenty-two photo reproductions of white juvenile court judges and European immigrant families and children, but not a single image of a person of apparent African descent; see T. D. Hurley, Juvenile Courts and What They Have Accomplished (Chicago: Visitation and Aid Society, 1904).

38. It lost popular support during the 1970 s when most prisoners were black. During FY1901 new prisoners were 78.4\% white and 21.6\% African American; see footnote 40. The report for 1914 shows fewer African Americans being admitted to Illinois prisons compared to 1901; compare Report of the Southern Illinois Penitentiary at Chester for the Two Years Ending September 30, 1914, 56. At the end of 1968 the carceral population was 50.3 percent black; see Illinois Department of Corrections, Population Analysis of the Illinois Adult Prison System (Springfield, IL, 1970), 14.

39. That these prisons were named as such and located in Vandalia and Dwight is documented in Illinois Department of Corrections, Fiscal Year 1997 Annual Report (Springfield, IL, 1997), 63, 110. The towns' sundown histories are described in Loewen, Sundown Towns, 235, 410-411.

40. The towns of Vandalia and Dwight are described as sundown towns in Loewen, Sundown Towns, 214, 234-6.

41. Khalil Gibran Muhammad, "Where Did All the White Criminals Go? Reconfiguring Race and Crime on the Road to Mass Incarceration," Souls 13 (2011): 72-90.

42. Muhammad, "Reconfiguring Race and Crime," 73.

43. Kenneth Allsop, The Bootleggers: The Story of Chicago's Prohibition Era (Geneva, IL: Hutchinson \& Co., 1968), 52.

44. Allsop, The Bootleggers, 52.

45. Paul L. Schroeder, Thirteenth Annual Report of the Criminologist (Springfield, IL: State of Illinois Department of Public Welfare, 1930), 3.

46. Herman M. Adler, Seventh Annual Report: Division of Criminology (Springfield, IL: Department of Public Welfare, 1924). Schroeder, "Thirteenth Annual Report." Illinois Department of Corrections, "Prisoners in the War on Drugs," in Insight into Corrections (Springfield, IL, 1990).

47. American Correctional Association, The American Prison: From the Beginning (USA: American Correctional Association, 1983), 148.

48. There were 12,968 people incarcerated in Illinois on July 1, 1940, compared to 6,100 in 1973. See "Annual Report of the Department of Public Safety" (1942), 22, and the table on page 14 of Illinois Department of Corrections, "Statistical Presentation 2001," accessed December 1, 2011, http://www.idoc.state.il.us/subsections/reports/statistical_presentation_2001/2001_statistical_presentation.pdf.

49. The Joliet-Stateville Time was started in 1937, "edited and published bi-monthly by and for the inmates of the Illinois State Penitentiary, Stateville Branch, Joliet, Illinois"; see JolietStateville Time 3 (June 1, 1939), 2. The Menard Time was started in 1932 as a prisoner-produced monthly and was published continuously until 1944; it was relaunched in 1949.

50. An unattributed article in the New York Times cites the course at Menard as the first college course offered in a prison in the United States in an unattributed article, "University Offers Prison Courses," October 28, 1956. The prison newspaper hailed the course; see unattributed, " 27 Men Enter Ivy-Covered Halls Via Extension Course," Menard Time 7 (September 1956): 2. (Note that 
Southern Illinois Penitentiary was referred to as "Illinois State Penitentiary at Menard" during this period.)

51. Jackie Spinner, "Drug Testing Dispute Kills Prison Degree Program," Daily Egyptian, August 8, 1988.

52. Vienna was used by Loewen to exemplify how a city becomes a sundown town by violently evicting all of its black population, as occurred in Vienna in 1954; see Loewen, Sundown Towns, 10.

53. Department of Public Safety, Annual Report of the Department of Public Safety (Springfield, IL: State of Illinois, 1967), 45.

54. Martin Luther King relocated to Chicago, where he was assaulted at Marquette Park in 1966, protesters clashed with Chicago police outside the Democratic National Convention of 1968, and the Chicago Police killed Fred Hampton, Chairman of the Illinois Black Panther Party, in 1969.

55. Illinois Department of Corrections, Population Analysis, 14.

56. A stunning example of Illinois prison town mentality can be found in the 1986 rap music video produced by community leaders from the former sundown town of Flora asking the governor to construct a prison in their town: "In a bid to promote the town as a prison site, Flora's former police chief recorded a song titled All We Want's A Prison, but the town failed to win its bid. Undaunted, a group formed the all-male Barbed Wire Choir. Their rap song, Is We Is, appealed for a prison in Flora, but attracted little attention until they turned it into a choreographed music video. Is We Is featured Flora's mayor Charlie Overstreet, its police chief Willie Thompson, unopposed mayoral candidate Bill Ridgeway, and the then-editor of the Clay County Daily Advocate-Press." The video is viewable online and features all-white mock juries and courtroom proceedings with choirs of white Flora residents making a direct appeal to the governor to build a prison in their town. See http:// www.youtube.com/watch? $v=q 5-\mathrm{d} 2$ WOgpfQ downloaded on April 3, 2012. Above quotation taken from same.

There are claims Flora was a sundown town; see http://sundown.afro.illinois.edu/sundowntownsshow.php?id=1869. During the late 1980s the prison population in Illinois was about 60 percent African American and 10 percent Hispanic.

57. See Alexander, The New Jim Crow, and Julilly Kohler-Hausmann, Getting Tough: Welfare and Imprisonment in 1970s America (Princeton, NJ: Princeton University Press, 2017), discursive practices that not only led to increased use of incarceration, but argue for "punishment" rather than programs and rehabilitation. Alexander focuses on the War on Drugs and the denial of services to convicted felons; Kohler-Hausmann focuses the origins of figure of the "Welfare Queen"-originally a woman from Chicago, before being generalized by Ronald Reagan in the 1970s - and their contribution to "getting tough" rather than providing for rehabilitation.

58. David Garland, The Culture of Control: Crime and Social Order in Contemporary Society (Oxford: Oxford University Press, 2001), 142.

59. Illinois Pub. Act 80-1099, eff. February 1, 1978 (1977 Ill. Laws 3264). In Illinois, felonies were divided into six classes: nonprobationable murder, nonprobationable Class X, and probationable classes 1-4. See Pamela L. Griset, "The Evolution of the Determinate Ideal of Sentencing: An Illinois Case Study," Law \& Policy 19 (1997): 265-284.

60. The chorus of the song refrains, "Is we is, or is we isn't, gonna get ourselves a prison?" See "Is We Is (Original Upload)," accessed July 30, 2016, https://www.youtube.com/watch?v=q5d2WOgpfQ.

61. Robert Martinson, "What Works? Questions and Answers about Prison Reform," The Public Interest (Spring 1974): 22-54.

62. Opening clause of the Mission Statement of the Illinois Department of Corrections, "Mission Statement," accessed July 30, 2016, http://www.illinois.gov/idoc/aboutus/Pages/IllinoisDepartmentofCorrectionsMissionStatement.aspx.

63. See Alexander, The New Jim Crow, and Chris Hedges, "Why Mass Incarceration Defines Us as a Society," Smithsonian Magazine Online, accessed November 26, 2012, http://www.smithsonianmag.com/people-places/Why-Mass-Incarceration-Defines-Us-As-a-Society-179994441.html. Loïc Wacquant, Prisons of Poverty (Minneapolis: University of Minnesota Press, 2009). Pedro A. Noguera, "Schools, Prisons, and Social Implications of Punishment: Rethinking Disciplinary Practices," Theory into Practice 42 (2003): 341-350.

64. A final and lasting example would be the denial of Pell Grant access, and thus college programming, for the prison population when the majority of people in prison were nonwhite in the mid-1990s. 